\title{
The incandescent light bulb phase-out: exploring patterns of framing the governance of discontinuing a socio-technical regime
}

\author{
Peter Stegmaier ${ }^{{ }^{*}} \mathbb{D}$, Vincent R. Visser ${ }^{2}$ and Stefan Kuhlmann ${ }^{1}$
}

\begin{abstract}
Research interest: This paper aims at a better understanding of the governance of the abandonment of socio-technical regimes through the example of the incandescent light bulb phase-out in the European Union and in the Netherlands as one specific case where the EU discontinuation policy has been implemented. In particular, with this paper we focus on the active and intended discontinuation of a socio-technical regime through dedicated governance.

Methods: We approached the phase-out of the incandescent light bulb from a qualitative perspective and analysed about 230 documents from the EU and Dutch level. The study has an explorative character, for we cannot claim to describe the entire policy process, but bring to surface some key issues in order to outline both governance foci and technicalities of governing the phase-out. We looked into how governance makers were actually structuring the ILB phase-out as a governance task. The specific framings we found were grouped into the (a) spectrum of governance dimensions, (b) the more detailed problem-types raised, and (c) the array of discontinuation issues addressed in policy discourse dedicated to negotiating, drafting and implementing the phase-out measures.
\end{abstract}

Results: A set of frames apparent in the discontinuation discourses in the EU and the Netherlands has been reconstructed, which entails the five governance dimensions 'policy instruments', 'implementation', 'strictness', 'monitoring', and 'policy level'. Technical details of both the socio-technical products to be banned and the replacing products have been the subject of meticulous negotiations in order to be able to implement the big picture, the lightbulb ban, appropriately and appropriately for both industry and environmental associations. The design of discontinuation governance at national and EU level are closely intertwined, but not identical in all aspects. The complexity of the governance task is therefore high.

Conclusions: Discontinuation has to cope with some resistance to dedicated, forced change that takes place in a technically as well as socially highly complex context. Governing the phase-out of a technical device, a production infrastructure, and industry support policy once supposed to support the EU and Dutch ILB industry was a major techno-political challenge, where policymakers needed to grasp key technical and technological problems. These were related to ILBs as objects, to subjects such as engineers and scientists, lobbyists and disinterested experts, to civil society organisations and mass media, along with all sorts of political and administrative issues and discourses. The challenges are threefold: first, translating for each other what cannot be known from one's own background, second,

*Correspondence: p.stegmaier@utwente.n

${ }^{1}$ Department of Technology, Policy \& Society (TPS), Science, Technology

and Policy Studies (STePS) Section, University of Twente, Postbus 217,

7500 AE Enschede, Netherlands

Full list of author information is available at the end of the article 
shutting down governance which so far fostered lighting industry and, third, helping to change parts of this industry from an old, incumbent one to a new, emerging socio-technical regime with a regime providing a political and regulatory framework for it.

Keywords: Discontinuation, Governance, Incandescent light bulb, Socio-technical regime

\section{Background}

\section{Discontinuation and its governance}

The governance of socio-technical regimes has preferentially been associated with advancement and innovation. Discontinuation of socio-technical regimes is, at most, discussed as regime change, innovation setback or failure-as if advancement and innovation was the only direction in which socio-technical development and its governance would go. Reasoning about the governance of socio-technical regimes maintains sometimes less, sometimes more of an advancement and innovation rationale (cf. [1-3], and innovation is then associated with growth and progress (for instance: [4, 5], critically: [6]). Regimes are seen as ongoing. Even when undergoing change, the regime seems to continue. Of course, there is the question to which level of a regime is change attributed: to the entire or to a (mere) subset of it. At the same time, wherever change is located and however wide or deep a regime is defined at the end of the day, the regime does not just move on, it has changed properties.

The multi-level perspective on socio-technical transitions provides at least a pathway pattern that leads to dealignment and substitution, implying that a certain kind of property of a regime is no longer continued, at least not as core characteristic [7]. Why should innovation not be associated with discontinuity as well-exit or phaseout could in some cases be the novel move, a governance approach to end a regime or/and an existing governance continuing the regime could be the real innovation. Discontinuation (cf. [8]) of socio-technical regimes is, at most, discussed as regime change, innovation setback or failure-as if advancement and innovation was the only direction in which socio-technical development and its governance would go. This paper aims at contributing to a better understanding of the governance of the abandonment of socio-technical regimes at the example of the phase-out of the incandescent light bulb (ILB). As observed since Schumpeter's [9] insight concerning the symmetry of creation and destruction, the anticipation of discontinuation and fading out is as important as the driving force of expectations about innovation and progress itself. It is crucial to see how technologies are recombined, getting unpopular, liquidated, how promises dissolve-in short: disappear over the horizon of a different future than the one, which was anticipated in the past. In particular, with this paper, we focus on the active and intended discontinuation of a socio-technical regime through dedicated governance. In doing so, we put the emphasis on Schumpeter's destruction dimension.

In this paper, we are following the question of how the incandescent light bulb phase-out has been implemented in the European Union and in the Netherlands. The paper is divided into five parts: firstly, we conceptualise the idea of 'discontinuation governance' (Sect. 2); secondly, we contextualise our case against the canvas of some broader patterns of discontinuation governance (Sect. 3); thirdly, we explain our methodology (Sect. 4); fourthly, we place exemplary emphasis on one of the cases, the phasing-out of incandescent light bulbs on EU and Dutch national level that spots light on how the five key dimensions of 'discontinuation governance' are realised in policy discourse (Sect. 5); and we end with conclusions and outlook for further research and policy uptake of 'discontinuation governance' as a strategic challenge (Sect. 6).

\section{Discontinuing socio-technical regimes}

Socio-technical regimes and their development patterns have been studied with various foci: rather broadly (cf. [10]), regarding growth and governance of larger sociotechnical systems $[11,12]$, path dependency $[13,14]$ and the transformation of established systems, e.g., by regime change [7, 15-17]. At some point, sooner or later, before broader success (e.g., $[18,19])$ or after years of broad success, a technology may become doubted (e.g., the internal combustion engine, cf. [20], delegitimised (e.g., Diesel in Germany, cf. [21-23], e.g., coal, cf. [24]), neglected (e.g., nuclear in UK, cf. $[25,26]$, be starting to start fade out, marginalised $[27,28]$ ), or be considered as failure [29-32].

A general, non-specific, notion for what is at issue here is 'regime change'. A 'socio-technical regime' ([33], p. 14, [15], p. 399-400) - the extended concept of Nelson' and Winter's [34] 'technological regime' - can be defined as a socio-technical configuration that fulfils a societal function, such as energy provision, transport, or housing (cf. [35], p. 2). This alignment and the interrelations of actors, institutions, activities and structures is a key for the stabilisation of the whole complex. Nevertheless, it can also give direction to change, making certain changes more likely than others, and "incremental changes more likely than radical changes" (ibid.). To round off the picture of regimes, the surrounding macro-level socio-technical 
landscape, external to the regime, needs to be taken into account ([7], p. 400).

Regime change, as understood by Smith et al. [36], is the interaction of two processes: (a) shifting (economic, legal, political, cultural) selection pressures on the regime, and (b) the coordination of resources available inside and outside the regime to adapt to these pressures (cf. [7], pp. 400-1). This model is realistic in so far as it includes both external and internal factors, factors of interrelation and factors of influence, as well as the agency dimension (transition trajectories enacted by social groups, structuration of activities in local practices; strategies and strategic interactions of involved actors; intended plans and unintended behaviour) ([37], pp. 29-31, [7], p. 402). Although policy discourses often superficially encourage such interpretations, it is a mistake for analysis to assume transitions to be self-evident, technical and deterministic processes, coordinated unambiguously and ex ante from the outset in explicit, centralised ways. In reality, also the coordination of discontinuity is an emergent, distributed and intrinsically ambiguous political phenomenon, unfolding in real time over the course of the transition itself (cf. [7], pp. 400, 402).

Discontinuation can be interpreted as one kind of regime change. In the light of the technological substitution pathway described by Geels and Schot ([7], p. 410) discontinuation can be thought of as the case when a technology drops off the present socio-technical regime as the result of (or at least associated with) a specific moment of shock in the broader political-cultural landscape. This may indeed hold true for the abandonment of nuclear energy right after the 1986 Chernobyl and 2011 Fukushima-Daiichi disasters. The shock hypothesis does, however, does not hold for the ILB phase-out, where there was no such shock event (if one does not subsume the finding that the market alone would in fact not make it possible to move away from incandescent lamps and switch to energy-saving lamps, and therefore would be necessary to ask for government measures to ban the incandescent lamp and reorder the European and global lighting market and industry sector, cf. McKinsey 2011; $[38,39])$. Rather it seems that more diffuse, less abrupt changes in the landscape and the offer of alternative technologies from niches (like energy-saving lamps and related technologies) can be associated with boosting discontinuation, in combination with policies and political initiatives pertinent for changes.

Another aspect to be studied further is the observation that sometimes no immediate technological alternatives are available in all respects, e.g., in the case of nuclear energy: while power plants in theory may be substituted by all kinds of non-nuclear energy generating systems, the grid infrastructure in Germany, in particular, is not yet ready to distribute large amounts of renewable energy across the country. The size, shape, and realisation of an appropriate grid is still furiously disputed among ministries (controlled by members of different parties) and local citizens' initiatives are taking a stand against wind turbines and transmission lines. Or take when the light bulb ban became effective, only energy-saving lamps, with technical faults, such as the delayed lighting time, also containing mercury and soon to be phased out under the Minamata Convention were available, as well as halogen lamps, many of which not very energy efficient and also about to be phased out, whilst LED lamps only years later became a viable alternative for users. In both cases, the politically intended destabilisation of the regime seemed to lead into a vacuum, which could not immediately be filled by the "emergence of multiple embryonic niche-innovations" ([7], p. 408). The de-alignment is thus sometimes decoupled from re-alignment (as the stabilisation of new actor networks, technologies and systems, regimes and policies), substitution and reconfiguration delays and the transformation romps around in a rather inconsistent state. Moreover, it remains to be seen how far the transition pathway $[40,41]$ and destabilisation [42] perspectives of existing regime change theory can be used, adapted, or substituted.

Utterback [43], while describing the role of technological evolution and innovation, narrates how the U.S. harvested ice industry demised as the result of the technical feasibility and economic success of first machine made ice and later electric refrigerators. In this case, an established and highly profit-yielding product and regime has been driven out of the market. Its place was takensometimes abruptly, sometimes gradually-by other technologies and products still offering ice and refrigeration, but by other means (as in the ILB case, where there is still lighting, but by other technological means than before). Utterback suggests:

"Generally, in any product market there are periods of continuity, when the rate of innovation is incremental and major changes are infrequent, and periods of discontinuity, when major product or process changes occur. Radical changes create a new business and transform or destroy existing ones." ([43], p. 84)

This summarising observation focuses on the level of markets for technologies and their innovations. Three dimensions inform the analytical framework: 'discontinuity' pertaining to a product or a process; a product substitution or a broadened market; for established industry, competence-enhancement or competence-destruction ([43], p. 89). A deeper elaboration has been suggested by Turnheim and Geels, emphasising a "neglected aspect 
of the transitions literature: the destabilisation of existing regimes and industries" ([42], p. 1). Reviewing and integrating various literatures, they consider "industry destabilisation is best seen as a longitudinal process that involves both external pressures (...) and endogenous enactment (...)" (ibid., p. 3) across several stages, such as disruptive innovations causing the decline of existing industries, as an economic decline process, driven by economic performance problems and shrinking financial resources, as a de-legitimisation process (ibid., pp. 2-3). Abandonment of socio-technical regimes occurs more often, then one might expect at first. Companies cancel devices, technologies and systems; a state agency like the NASA has a long track of stopping systems before or after start-up. While Utterback focuses at 'discontinuity' as market phenomenon and Turnheim and Geels view 'destabilisation' as a regime transition phenomenon, we aim at deliberate and active discontinuation. Considering discontinuation as a problem of action for policymakers [44].

Utterback ([43], p. 84) sees such continuity and discontinuity following predictable patterns. However, we would argue, it is utterly difficult to predict the more concrete patterns of discontinuation in terms of a point or phase in time, necessary or sufficient conditions, emerging or set in motion intentionally. Rather, as the case of nuclear energy in Germany teaches a once achieved termination may sooner or later be revoked and even recanted-only to be itself taken back after some time $[25,45,46]$. It is utterly hard to predict how many withdrawals from withdrawals and continuations will occur until a socio-technical regime is all over and past. These backward and forward movements may be an indicator for the destabilisation of socio-technical regimes, but also one for what major undertaking it is to abandon a regime actively.

Since we are not looking at the operation of a regime as such, but at purposeful action undertaken to terminate a socio-technical regime, we also need to create a suitable governance perspective (cf. [47]). Discontinuation as governance task and problem can be understood starting from works on policy termination ([48] for an overview; see also [49-53]). Van der Graaf and Hoppe ([54], pp. 221-227) suggest to see policy termination as "result from a changed formulation or perception of a policy problem or from a changed formulation or perception of a policy solution" ([47], p. 114; cf. [55], pp. 250-254). In addition, with understanding discontinuation as governance we are pointing at the fact that we found far more actors than only government and politicians involved (although, in the Dutch case, see 5.2, we decided to once limit the analysis to members of parliament and ministers only). Discontinuation governance in this paper is understood as an interpretive process, "in the course of which problems (of defining questions and answers, difficulties and-possible-solutions) are negotiated and enacted in politicised interactions" ([47], p. 113; cf. [56]; [57]). With governance, we mean "those efforts that aim to initialise or end, align or de-align, with a binding character, concerted action across multiple, competing modes of making, maintaining, and destabilising social order for public or private purposes" ([47], p. 113) which are "denoting the dynamic interrelation of involved (mostly organised) actors, their resources, interests and power, fora for debate and arenas for negotiation" ([58], p. 6).

\section{Patterns of phasing out socio-technical regimes}

There is a number of relevant present-day cases of purposeful discontinuation of socio-technical regimes and their surrounding infrastructures. Recent examples of discontinuation (cf. [20,59-61]) indicate the significant pace and political momentum that can be acquired in such initiatives. Each case exemplifies in different ways the policy pace, political will and institutional momentum required in order to transform wider governance environments so as to achieve such large-scale shifts in socio-technical infrastructure. Discontinuation governances have quite different characteristics. Some apply only to one case (e.g., 'partial replacement' to the combustion car engine in Germany and other countries; in Sweden it has been decided to also build nuclear power plants only in order to replace out-dated ones, but no additional new ones); or to a few (for instance, the production of very specific light bulbs has been ceased in all countries, whereas only the usage, but not the production of DDT has been stopped). Regarding 'aftercare' [47], governance has not only the problem of fading out the regime, but also that of deconstructing the physical system and managing the waste after the last atomic power plant will have been taken from the grid. Further analyses might show that the same could apply for DDT. Gabel [62] presents a detailed case narrative in which companies cease chlorofluorocarbon (CFC) production in reaction to public policy banning first some uses and anticipating on possible further bans by increasingly coordinating with policy to exit from CFCs entirely (Montreal Protocol of 1987).

If we look at the process dynamics, we find in all cases incremental steps toward ending a socio-technical regime, in the case of nuclear energy and ILBs in combination with full exit decisions. Often forward/backward decision-making characterises the challenge put on a technology and regime, in the case of nuclear energy in Germany the binding decisions have been revised several times within a decade. Germany, even though not being the first country in Europe to stop nuclear power (Italy, 
Spain, Belgium did so earlier), could still have a pioneering role as the largest economy in Europe and worldwide to stop this technology along the entire (material, perhaps not so much the knowledge) infrastructure. Quite normal is a certain degree of transnational (at least European, or worldwide) coordination on technology exits, while nuclear energy has been abandoned in individual countries without any noteworthy coordination among the protagonists. It cannot be excluded that "through the alignment of visions and activities of different groups" ([7], p. 402) more coordination along informal, unintended or/and newly developed channels may emerge. The same is true for the quite heterogeneous patterns of using (positive and negative) sanctions and making differences between usages and markets to which the stops are applied.

In the following, we reconstruct phase-out policy discourses regarding incandescent light bulb (ILB) technology and derive first indications of the problem structures and processes of active discontinuation as a governance project of the European Union and how it is realised in the Netherlands as EU member state.

\section{Methodology}

For this paper, we approach the issue of the phase-out of the incandescent light bulb from a qualitative perspective. This means we have looked into central communication efforts around this governance task in order to reconstruct the guiding governance problems $[44,63]$ and their operationalisation in policy documents from a discursive point of view (cf. Table 1). So, we examined the policy process as far as this is determined by the documentation and documents instrumental to the process; as far as it appears in acts of policy communication and in the ways the crucial issues of making that governance effort work are framed. We have analysed about 230 documents from the EU and Dutch level. The documents from the EU are drawn from the commission's data base, while the Dutch documents of parliamentary proceedings have been retrieved from the data base of the Second Chamber ("Tweede Kamer"), the Dutch Parliament. The study has an explorative character, for we cannot claim to describe the entire policy process, but bring to surface some key issues in order to outline both governance foci and technicalities of governing the phase-out. In doing so, we focused on the protocols and documents of the interest groups involved, which were created within the framework of the coordination process in accordance with the MEEuP (Methodology study for Ecodesign of Energy-using Products; cf. [64, 65]), defined within the Ecodesign framework. Here, we mainly looked into the adoption of domestic lighting into the Ecodesign framework, then the open public consultations (EUP4Light),
Table 1 Preliminary heuristics for analysing discontinuation governance $[59,60]$

\begin{tabular}{ll}
\hline Guiding problems & $\begin{array}{l}\text { Operationalisation } \\
\text { problems }\end{array}$ \\
\hline Exiting & Abandonment \\
& Construction stop \\
& Partial replacement \\
& Aftercare \\
& Incremental steps \\
Process dynamics & Forward/backward decisions \\
& Pioneering \\
& Transnational coordination \\
& Ban \\
Policy instruments & Pricing, permits \\
& Research \\
& Purchase subsidies \\
& Alternative offers \\
& Usage \\
Scope & Home/foreign markets \\
& Official/private ending \\
Local, national, supranational & governance levels \\
Specific regulations & Justification \\
&
\end{tabular}

followed by several closed expert meetings called 'Consultation Forums' and protocols from the European Parliament addressing the phase-out. The technicalities are both the technoscientific and political details, as well as their combinations, the governance practitioners have to deal with.

Frames are "a way of selecting, organizing, interpreting and making sense of a complex reality to provide guideposts for knowing, analysing, persuading and acting" ([66], p. 146). They function as a principle of organising thoughts, emotions and volitions governing the subjective meaning we assign to social phenomena. Although framing limits choices, they are necessary to make action and judgment possible at all. Actors need frames as a sort of mental grappling hook. Here, we look into how governance makers were actually structuring the ILB phase-out as a governance task. ${ }^{1}$ Policy discourse is

\footnotetext{
When we speak of governance makers, this of course implies not only government actors, but also those from industry and numerous other interest groups who were involved in the consultative procedures in preparation for the ILB phase-out. This means industry, for instance, is there in the data and analysis, just not on the reporting level of this paper, because it has not got an actor-analytical focus. Philips and Osram are indirectly part of the negotiations documented and analysed, and most often represented by their lobby organisation ELC (European Lamp Companies Federation) and CELMA (Federation of National Manufacturers Associations for Luminaires and Electronical Components for Luminaires). We also included their relevant position papers in the analysis.
} 
"the interactions of individuals, interest groups, social movements and institutions through which problematic situations are converted to policy problems, agendas are set, decisions are made and actions are taken" (ibid., p. 158). The specific framings we found were grouped into the (a) spectrum of governance dimensions, (b) the more detailed problem-types raised, and (c) the array of discontinuation issues addressed in policy discourse dedicated to negotiating, drafting and implementing the phase-out measures. To organise the data, we used the ATLAS.ti software, which we used according to the grounded theory principle of open, axial and selective interpretation and analysis of data [67].

Our focus clearly is on the regime dimension, with only occasional attention for niche and landscape dimensions. This paper is thus not aimed at a full multi-level analysis.

\section{Results}

\section{Phase-out of the incandescent light bulb technology}

Although many new types of energy-efficient light bulbs have entered the market, the ILB is often used for domestic lighting. Although this bulb has proven itself over the years, the bulb has been discussed for its energy waste. As a result, various policy initiatives have been launched around the globe to phase out the energy-inefficient light bulb ([68], pp. 2-7). Finally, in 2009, an EU directive was presented for the gradual phasing-out of household lightning to reduce the greenhouse gas emissions [69]. This is described in detail in the following Sect. 5.1. The setting of the agenda for governance changes ("establishing the problem”) was reconstructed from online available policy documents. In the different European Member States, the discontinuation of the ILB was also discussed as a policy issue. We have reconstructed the Dutch ILB ban governance as documented in policy documents (Sect. 5.2).

For this, we have not simply subsumed the data under the categories outlined in Sect. 3 (cf. Table 1), but developed case-specific categories covering the main framing patterns for the data materials and the ILB focus in particular. This led us, from a comparative point of view, to both different and similar aspects that altogether should be recognisable from a practitioner's viewpoint as realistic coverage of their negotiation topics.

\section{ILB phase-out governance on EU level}

ILB technology has been phased out from 2009 to 2013 through EU regulation 244/2009, which is based on the Eco-Design of Energy-Using Products Directive 2009/125/EC. We have described the ILB phase-out policy process elsewhere [47]. At this point, we just need to hint at some circumstances that help laying out the context of the active ILB discontinuation.
Different speeds The European Union came 4 years after Brazil and Venezuela who were the first to start phasing ILB out in 2005. In the EU, immediate discontinuation applied first only to general-purpose, non-directional incandescent bulbs of 100 watts. The limit moved down to lower wattages step-by step, as the efficiency levels raised by of 2012 in steps. Different speeds could also be observed between official and private phase-out regarding the usage: retailers in many EU countries have reported bulk purchasing through consumers, who thus extend the phase-out in private realms beyond the official deadlines. $^{2}$

Policy diffusion, broad policy base The policymaking trajectory of the ecodesign regulation for the discontinuation of the ILB started with a push for the phasing-out of the ILB in domestic lighting aiming to stimulate the use of energy-efficient lighting. The agenda setting for this involved various different actors, including industry, NGOs, and political parties. Different interest groups pushed for the discontinuation of ILBs. Edge and McKeen-Edwards ([68], pp. 2-7) explain that an important reason for this was the rather low-costs of discontinuation policy and the ease of implementation due to widespread support from industry and environmentalists. The need for a policy against ILBs was mainly explained with sustainability considerations. The wide sharing of this reason was reflected in proposals of the European Lamps Companies Federation (ELC) to phase out the ILB before there was any regulation [70]. Several member states had already introduced or discussed first policy initiatives to phase out ILBs [71]. They were also part of global policy diffusion concerning the ban or phase-out of incandescent light bulbs (see Fig. $1^{3}$ ) that manifested itself, for instance, in the Phase-Out 2008 Conference held in Shanghai attended by delegates, from across the spectrum of governance actors, from over 20 countries.

Existing framework as basis The policymaking process for a final regulation on the discontinuation of the ILB in the EU was mainly facilitated and structured by the European Commission, due to its embedding in the ecodesign directive. The Ecodesign Directive $[64,72]$ is a framework regulation to improve the environmental performance of energy-using products through ecodesign requirements. Ecodesign requirements aim to set new standards for the design of a product to improve its environmental

\footnotetext{
2 Many shops in Germany sold $80-150 \%$ more light bulbs in the first half of 2009, as Spiegel (www.spiegel.de/spiegel/vorab/0,1518,638227,00.html, accessed 16 February 2012) reports. Cf. 'Light bulb saving time' by Penelope Green in the New York Times, May 26, 2011 (www.nytimes.com/2011/05/ 26/garden/fearing-the-phase-out-of-incandescent-bulbs.html, accessed 7 November 2019).

3 'Improved bulb' is the general term used for the light bulb that replaced the filament for a halogen lamp. These bulbs have the same characteristics as the classical bulb, but are $25 \%$ more efficient. They were allowed until 2016 as a way to make the transition easier.
} 


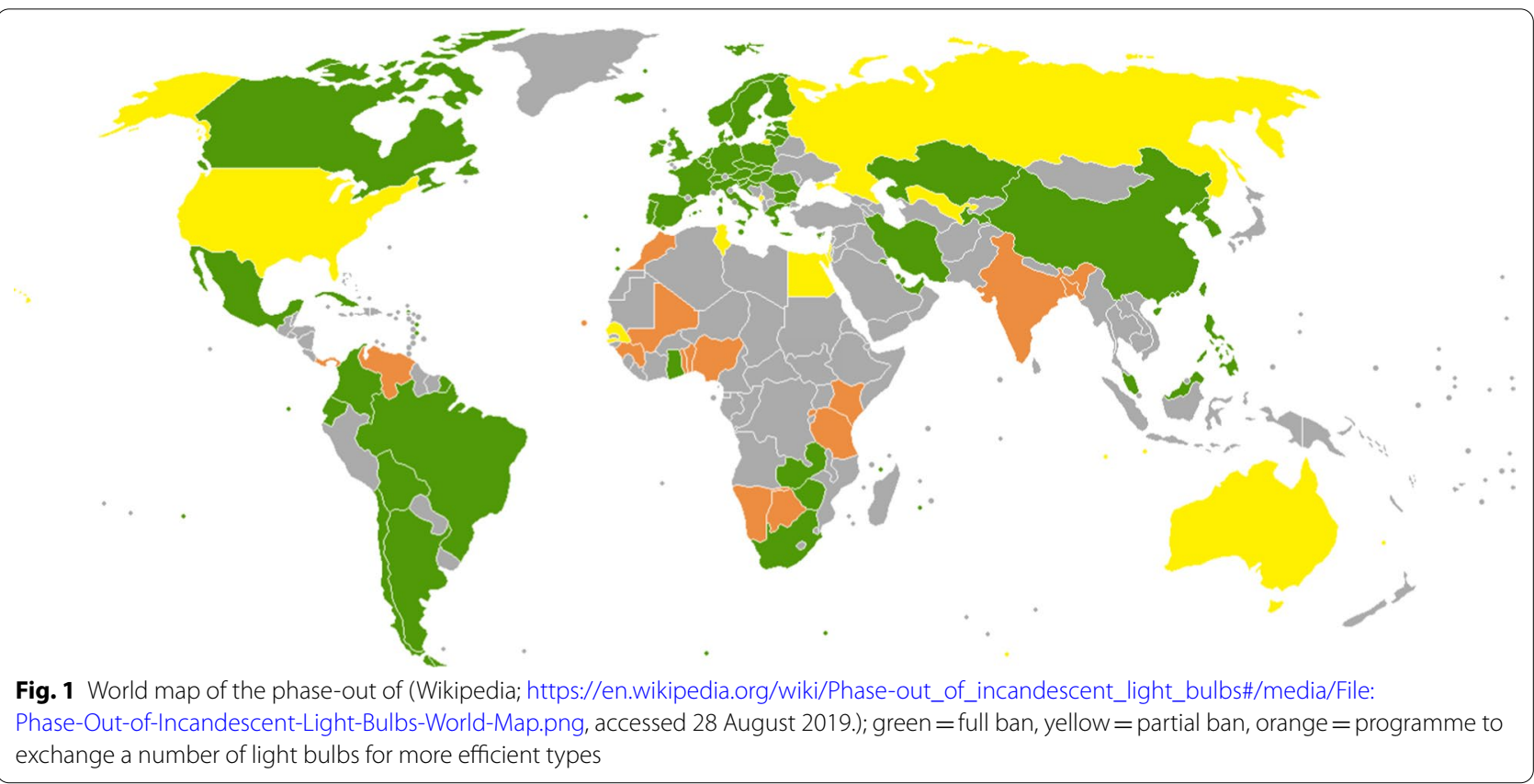

performances or improve the supply of information on its environmental aspects. This ecodesign framework operates on the supranational level to overcome separate national legislation and preserve the free movement of goods. For domestic lighting, an ecodesign regulation was proposed to improve the energy-efficiency performance of lamps and their environmental performances. The push for discontinuation of the ILB led to the inclusion of domestic lighting as a product group in the ecodesign framework. As part of the ecodesign framework, the policymaking process for ecodesign requirements has been facilitated and pre-structured by the European Commission through established approaches and methods in the course of its policymaking.

Table 2 presents an overview of the governance dimensions of ILB discontinuation that were proposed and discussed during the EU policymaking trajectory, as well as the involved trade-offs. These governance dimensions represent the policy choices that were considered by the involved actors for the design of a discontinuation policy.

In the following, the governance dimensions are explained based on relevant policy documents.

\section{Policy instruments}

The discussion on the discontinuation of inefficient lighting was focused on the use of appropriate policy instruments. All the actors debated the introduction of efficacy requirements for domestic lighting. The ELC was one of the first parties that presented a plan for the termination of the ILB by setting efficacy requirements: "For each phase, there would be minimum efficiency specifications
Table 2 The governance dimensions and the trade-offs on EU level

\begin{tabular}{ll}
\hline $\begin{array}{l}\text { Governance } \\
\text { dimensions of } \\
\text { discontinuation }\end{array}$ & Trade-offs \\
\hline Policy instruments & Efficacy requirements vs. additional requirements \\
Implementation & Immediate ban vs. gradual transition \\
Strictness & Exceptions for use vs. no exceptions for use \\
Monitoring & Business as usual vs. additional regulations \\
Policy level & National vs. supranational \\
\hline
\end{tabular}

based on an energy efficiency classification [...], and on luminous efficacy or lumens per watt [...]." ([70]: 1). Subsequently, efficacy requirements for domestic lighting were also an important part of the ecodesign framework. The aim of the ecodesign framework was to set a new standard for the production of light bulbs, which eventually would lead to the termination of inefficient lighting like ILBs. The EUP4light project-installed by the European Commission in order to be able to formulate ecodesign requirements for domestic lighting, and carry out a technical, environmental and improvement analysis of domestic lighting in a fixed format [73] — did a comparison of the different ecodesign scenarios for phasing out inefficient domestic lighting. These ecodesign scenarios were mainly based on raising the energy efficiency classes 
of lighting with subsequent phases, so the inefficient lamps that could not satisfy these efficiencies would have to be phased out or need to be improved: "In the tables presenting the scenarios (except for the BAU), minimum requirements (i.e. minimum energy class) are set for each tier. In order to analyse these scenarios, a specific lamp technology is used as replacement lamp" ([73], p. 242) as a way to reach the requirements.

Within the final ecodesign regulation, minimum efficiency requirements were a central aspect for the phasing out of inefficient lighting. The European Commission underlined that "efficiency requirements should be set at levels that would lead in practice to a phase out of traditional incandescent bulbs (GLS) used for general lighting purposes" [74]. . However, besides energy efficiency, the European Commission also addressed the need of additional requirements for lamp functionalities and product information for the replacing lamp types: "requirements are also set on the functionalities of the concerned lamp types [...] and on the product information to be displayed to allow the consumers to better select the appropriate lamps for a given purpose among the alternatives to conventional incandescent lamps." ([75], p. 17).

So, raising energy efficiency requirements for domestic lighting formed an important part of the policy instruments for the dedicated discontinue of ILBs by setting new standards for domestic lighting. Besides the discussion on the appropriate efficacy requirements for a discontinuation policy, also additional requirements were increased. These additional requirements for phasing out of ILBs were discussed to overcome certain consequences of a phasing out and to establish an appropriate discontinuation trajectory. Thus energy-efficiency requirements were not the only means for governance dimensions needed for phasing-out. As the dimension 'policy instruments' is concerned additional ecodesign requirements (besides setting new energy-efficient requirements) were discussed as well. Different requirements were discussed, but all related to the identified discontinuation barriers/ trade-offs that were found in the sources.

\section{Implementation}

The previous section showed that the main focus of the discontinuation policy was to phase out ILBs and other inefficient lighting by setting energy-efficiency requirements. However, the pace of this phasing out was highly debated. From the start, a gradual discontinuation was preferred over an immediate ban. The European Commission explained that a ban would have an advantage

\footnotetext{
${ }^{4}$ GLS is the abbreviation for General Lighting Service, the conventional light bulb used since the early twentieth century.
}

for energy savings, but would mitigate impact on industry and supply: "Staged introduction of requirements (in particular banning incandescent bulbs in several stages) would affect accumulated savings up to 2020 but mitigate impacts on industry and should avoid risk of supply shortage; the annual savings as from 2020 would remain more or less unchanged." ([76], p. 56). Although there was consensus about the advantages of a gradual replacement of lighting, there was discussion about the timing and ambition of this replacement: "All the examined options lead to a total phase out of traditional incandescent bulbs (GLS) used for general lighting purposes [...]. The main questions for debate are the level of ambition beyond phasing out GLS and timing” ([77], p. 2).

The decision on the pace of discontinuation was argued to be influenced by the level of ambition of the setting of the ecodesign requirements and the timing for the setting of these requirements. The Consultation Forum members divided two types of timing: 'ambitious timing' and 'cautious timing' ([77], pp. 9-10). The 'ambitious timing' was proposed during the EUP4light project: a phase-out with three stages in 5 years [73]. The lighting industry (ELC and CELMA) ${ }^{5}$ proposed a phase-out of five stages in 9 years [78]. Besides the ambition of timing, also the ambition of the requirements for these stages was discussed among the stakeholders, which included environmental and health NGOs, civil society organisations, technical experts, industry representatives, and lobby organisations besides Member States and European Commission Services. The EUP4light discussed several options and proposed three of them to the European Commission and the Consultation forum ([77], pp. 7-8). 'Option one' contained a final minimum energy efficiency requirement of eco-labelling level A: only efficient CFLs (compact fluorescent lamps) ${ }^{6}$ allowed. 'Option two' had a final minimum energy efficiency requirement of level $A$ with some exemption in level $\mathrm{B}+$ and $\mathrm{B}$ : this would have allowed improved incandescent light bulbs in some cases. The least ambitious 'option three' that put the energy efficiency requirement on level $\mathrm{C}$ would have phased out all ILBs but left some options for halogen lamps.

So, besides defining the appropriate policy instruments for a discontinuation policy, also the implementation of the policy was widely discussed. A major part of the

\footnotetext{
CELMA is the Federation of National Manufacturers Associations for Luminaires and Electrotechnical components in the European Union.

6 From today's point of view, it may look strange that LED lamps have not discussed much, because nowadays they are so ubiquitous. Maybe we should remember that policymakers then seemed to be waiting for the 'breakthrough' of the LED. The common believe was that CFLs produce ugly light and LED lamps are mainly decorative and very expensive. This could also be an indication of why ILBs were still popular at the time and why there was a need to stimulate more efficient lighting, both for consumers and industry.
} 
actors appeared to be in favour for a gradual termination of inefficient lighting. However, the ambition and timing of the implementation of the proposed requirements were highly debated. Several different scenarios were developed and discussed, but the European Commission and the Consultation Forum had the final say.

\section{Strictness}

The above plans led to a discussion about the room for an exceptional use of the discontinued lamp types. In the EUP4light project, the need for the use of the discontinued lamps in specific circumstances was explicitly mentioned: "Banning of products or technology from the market based on its 'efficacy' could therefore cause serious negative side effects for other light source applications." ([73], p. 298). Examples of the application of special purpose lamps were summed up by the ELC: "In the domestic market: Oven lamps, Fridge lamps and other appliance lighting ... Other applications that would be severally impacted ... would be Theatre, Stage, studio \& the entertainment industry. Also, indicator lamps, airfield E aircraft lamps." ([79], p. 90). Exceptional use of discontinued lamps was also requested for people that are sensitive for light: "Following the precautionary principle, there is also a need to keep alternatives to CFL lamps for some patients with alleged health issues. This means leaving certain transparent halogen lamps on the market" ([76], p. 55). A solution for these issues of special uses of inefficient lighting was proposed by the ELC by lowering the efficacy requirements of $25 \mathrm{~W}$ lamps: "The majority of the lamps under $25 \mathrm{~W}[. .$.$] have a lower environmental$ impact due to their power [...] frequency of use [...] and their market size [...] Furthermore, cost-effective, energy efficient alternatives for many of these lamps are not yet available on the market." ([80], p. 4).

In the final regulation, the European Commission left room for the use of less energy-efficient lamps in two ways. First of all, they left the option open to allow the production and use of improved incandescent light bulbs: "current-day compact fluorescent lamps and light emitting diodes cannot provide the same type of light as the conventional incandescent lamps [...] improved incandescent bulbs with halogen technology do, and consumers who are keen on conventional incandescent light quality for aesthetics or health reasons should have access to it." ([81], p. 9). And secondly, they made exceptions for special purpose lamps in their final regulation: "the following information shall be clearly and prominently indicated on their packaging and in all forms of product information [...]: (a) their intended purpose; and (b) that they are not suitable for household room illumination." ([75], L76/6).

Thus, the phasing out of inefficient lighting also stirred up the debate on the need for exceptional use of the discontinued technology. It was argued that for some occasions energy-efficient lighting was not appropriate or feasible. This opened up the debate on scope to reduce, in some cases, the strictness of the governance of discontinuation. In the final regulation, the European Commission has decided to temporarily allow improved incandescent lamps and to grant a special exemption to the special purpose lamps for the efficacy requirements.

\section{Monitoring}

Besides the constitution of a discontinuation policy for inefficient domestic lighting, the actors involved also discussed the monitoring of this policy. The enforcement of the policy by market surveillance was often called an important condition for the enforcement of a fair competition. The ELC argued that effective enforcement of market surveillance by Member States was necessary for a successful outcome of the legislation: "Without this [effective Member State enforcement], ELC fears that illegal free riders will undermine the potential benefits of the legislation, to the detriment of consumers, companies making genuinely conforming lamps, and ultimately wellintentioned legislators." ([82], p. 1). The question of effective market surveillance by the Member States was also noted during the Consultation Forum ([83], p. 6). However, it was assumed that no additional regulation would be needed to improve this market surveillance for the implementation of the discontinuation policy. A member of the European Commission, Günther Oettinger, explained: "The role of the Commission is to provide (where appropriate) opinions on the decisions taken by the Member States in the framework of their market surveillance activities, and to keep the other Member States informed of the decisions taken by a particular Member State." [106]. This shows that the monitoring of the discontinuation policy was mainly perceived as part of the framework of the usual market surveillance activities of the member states.

Another part of the discussed monitoring was the evaluation of regulation over time. The European Commission explained that monitoring not only included market surveillance, but also the monitoring of the appropriateness of the policy over time: "The appropriateness of scope, definitions and concepts will be monitored by the ongoing dialogue with stakeholders and Member States. $A$ review of the measure should be planned taking into account market evolution and in particular the development of LED technology." ([76], p. 17). Although there did not seem to be a specific deadline for the revision of the rules regarding the ecodesign of lighting products, policymakers assured that policy adequacy was also monitored. 
In brief, the monitoring of the established policy was discussed from two perspectives. First, market surveillance was considered necessary to monitor the enforcement of the phasing out policy. However, no additional policy measures were discussed as the existing market surveillance framework was considered effective enough. Secondly, the evaluation of the appropriateness of the discontinuation policy was also seen as an important part of policy monitoring. This evaluation was especially linked to innovations in the field of lighting.

\section{Policy level}

The level of policymaking for the ILB discontinuation was not much discussed by the actors involved during the formal course of policymaking. The important legitimation for this supranational approach was the subsidiary principle. A member of the European Commission, Andris Piebalgs, explained, a supranational policy will discontinue inefficient lighting in a harmonised way: "The subsidiarity principle is respected, as diverging national requirements on products [...] would have posed obstacles to the free movement of goods within the Community." ([107], p. 1 ). This means that the EU would ensure that common standards apply across the entire common market, so that rules and laws are coherent between all Member States, thereby reducing the regulatory burden on businesses. The cost of different national legislation has also been cited as an important reason for choosing a supranational policy: "The form of the proposed legislation is a regulation which is directly applicable in all Member States. This ensures no costs for national administrations for transposition of the implementing legislation into national legislation." ([76], p. 43). In this way, the supranational level of the policymaking has been found to be beneficial because of the standardisation in the different Member States.

However, not all actors agreed that supranational legislation on the EU level would meet the requirements of a discontinuation policy. On the one hand, several MEPs have petitioned to explain the need for an international discontinuation: "Urges the Commission to use the proposal for a new international energy efficiency agreement to launch a global ban on the use of incandescent bulbs." ([84], p. 2). On the other hand, a declared opponent of the EU from the UK Independence Party, doubted the democratic legitimacy of the banning of the ILB, due to its underhand and undemocratic procedure: "The initial directive handed implementing measures to the European Commission which, in effect, meant that the regulation was allowed to pass without the consent of this farce of an Assembly or of my real parliament at Westminster." [85]. Some of the opponents of the supranational level wanted to transcend the standardisation to an international level. Other opponents argued that a supranational level had overridden political initiatives at national level and was not democratically legitimised. The latter used the ILB to pursue their anti-EU agenda; the first aimed at going even beyond EU level while applauding the EU-wide ban.

So, the choice for the level of the discontinuation policy has triggered some debate about the legitimacy of the supranational level of a discontinuation policy. Within the EU policymaking trajectory, the level was not really debated. It seems that among the actors involved the legitimacy of the supranational policy was justified, above all, by its results as a harmonised regulation applicable to all Member States and the internal market.

The five different governance dimensions discussed above represent different trade-offs for constituting a break-up path for inefficient lighting by setting new technical standards for domestic lighting. Different choices were considered as discontinuation policies: not only energy-efficiency requirements, but also other policy means were discussed. The policy options involved were seen as ways to overcome a number of discontinuation issues, as shown in the following table.

Table 3 is the result of the reconstruction of the governance dimensions that were attributed to the different discontinuation problems found in the analysed policy documents. However, it has to be said that the actors involved have not explicitly identified some issues as a governance task, and others have been designed to be resolved in terms of more than one governance dimension. The 'performance issues' (burdens of replacing technology) and the 'image issues' (burdens of/for users) are mentioned twice, because they were attributed with two different governance dimensions. The image of the new lamps was a lot worse than the new one because, among other things, there were problems with the cold light colour, poor colour rendering, high weight, which the customers did not like ([73], p. 111). Absent are the 'need for improvement (burdens of replacing technology), 'change of use' (burdens of/for users), 'retrofitting' (burdens of infrastructure), and 'costs of discontinuation' (challenges for industry) because they were not perceived as issues that should be solved as a governance task. ${ }^{7}$

To clarify which governance problem-types the discontinuation issues correlate with, this relationship is discussed below.

\footnotetext{
7 This table shows that the actors identified not all problems as a governance task, which means that the problems were raised, but not linked to one of the dimensions that were said they needed to be solved.
} 
Table 3 The governance dimensions and the related problems on EU level

\begin{tabular}{|c|c|c|}
\hline Governance dimensions & Problem-types & Discontinuation issues \\
\hline \multirow[t]{11}{*}{ Policy instruments } & Burdens of replacing technology & Performance issues \\
\hline & & Impact of production and use of resources \\
\hline & & Recycling \\
\hline & & Health issues \\
\hline & Burdens of/for users & Awareness raising for need of discontinuation \\
\hline & & Need of knowledge for replacement \\
\hline & & Comparison of light output of new lamps \\
\hline & & Image-issues \\
\hline & & Stockpiling of ILBs \\
\hline & & Costs of discontinuation \\
\hline & Burdens of infrastructure & Need for new eco-labelling \\
\hline \multirow[t]{2}{*}{ Implementation } & Challenges for industry & Capacity for new production \\
\hline & & Production loss due to discontinuation \\
\hline \multirow[t]{3}{*}{ Strictness } & Burdens of replacing technology & Performance issues \\
\hline & Burdens of infrastructure & Retrofitting \\
\hline & & Dim-installation \\
\hline \multirow[t]{4}{*}{ Monitoring } & Burdens of replacing technology & Recycling \\
\hline & & Health issues \\
\hline & Burdens of/for users & Image-issues \\
\hline & Challenges for industry & Circumvention of industry \\
\hline \multirow[t]{3}{*}{ Policy level } & Existing regulations & National level \\
\hline & & Supranational level \\
\hline & & International level \\
\hline
\end{tabular}

\section{Burdens of replacing technology}

Several policy instruments have dealt with the fact that new and efficient lamps must replace the discontinued lamps. Initially, the attribution of additional requirements for new technology was an issue. For some of the performance issues, additional requirements have been introduced to force the industry to improve specific features of the new lamps. Additional directives govern both the environmental impact of the production of energy-efficient lighting and the need for recycling. The health issues ${ }^{8}$ associated with use of the use of new illuminants also provided an additional policy tool, health report review. In addition to concrete policy instruments, the ecodesign requirements have been lowered in order to overcome performance issues of the new lighting technology. This does not mean that the final need for new lighting has been changed, but only the transitional period. For example, the 'improved bulb' would phase out in 2016 as well. Therefore, the transitional period has been extended to allow the industry to adjust and improve the new technology. As a result, effective monitoring of the consequences of recycling and health issues was considered an important governance

\footnotetext{
8 Light sensitivity (flicker, electromagnetic fields and ultraviolet/blue light radiation), skin sensitivity, mercury content (lamp breakage).
}

tasks. In contrast, the need for improvement of energyefficient lamps was not perceived as a governance task, but was believed to be solved over time by technological innovations.

\section{Burdens of/for users}

Improving consumer education and awareness was the key strategy to solve the problems associated with the use of replacement lighting technology. Policy instruments have been proposed to stimulate consumers information and awareness on the need of knowledge for replacement, and image issues. The costs of discontinuation were also aimed to be reduced by providing better information about the improved life cycle costs of the new lighting. A more specific policy instrument has been attributed to the comparison of light output. For this problem, standardisation of the output level indicated on the package was required. The rebound effects of discontinuation as the result of the altered behaviour or stockpiling of ILBs were not considered a governance task. 


\section{Burdens of infrastructure}

It was found that the existing infrastructure causes different discontinuation issues. By temporarily reducing the stringent efficiency requirements, the problem of retrofitting and non-applicable dimming systems for the new lighting technology was solved. Apart from the use of so-called "improved ILBs", the issue of harmonic interference was not considered a governance task. Finally, the issue of the out-dated ecolabel system was solved by introducing a new and updated system as an additional policy measure.

\section{Challenges for industry}

Implementation of the discontinuation was seen as a central theme for the industry. The discussion about the pace and timing of the expiry of ILB dealt with the issues of new production capacity and production downtime. It has often been argued that the changes in manufacturing required a deliberate implementation speed. Another challenge for the industry, the avoidance of weaning requirements by other industrial players, has been largely addressed as a monitoring task.

\section{Existing regulations}

Existing regulations were discussed mainly with regard to the question of how high the level of discontinuation governance would be. The supranational level for discontinuation regulation has not been much discussed. However, with regard to existing policy initiatives or laws, it has often been argued that they could best be resolved through supranational policies.

\section{First intermediate conclusion}

This review of governance issues shows that the selection of tasks for direct governance efforts and those for further technological development under pure monitoring was the subject of negotiation. Thus, it is justified to speak of a governance of discontinuation, as there was a process in which roles and responsibilities were distributed between various actors and across different governance levels. The discontinuation in the case of ILBs was linked to expectations about and achievements of the technological innovation-the discontinuation, in this case, is built upon the availability of a replacing technology. Although the replacing technology is, from some points of view, not yet seen as perfect, the discontinuation of the old was acceptable for most stakeholders in the moment were the technology and its related infrastructure had reached a level of perceived maturity. It has also been proven that not only the old technology would be subject of abandonment, but also the technical standards that would have to be lowered to allow for more flexibility in the not yet fully comparable quality and usability of the new illuminants.

In order to contrast and complement this analysis of the targeted control of ILB at the supranational level, the next chapter will shift the focus of analysis to the Dutch national level.

\section{ILB phase-out governance on Dutch national level}

We have also analysed for the Netherlands various actors' governance problems and strategies of ILB discontinuation. We focussed on assessing proceedings of the Dutch parliament (in which questions were officially asked by members of parliament and answered by the government; partially, the questions and answers were exchanged in written form), at times before and after the ILB discontinuation was finally decided on EU level. ${ }^{9}$

The aim was to reconstruct from documents the frames used in discourses setting the agenda for discontinuation ("establishing the problem"). We start from assessing proceedings of the Dutch parliament (questions officially asked by members of parliament and answered by the government), before and after the ILB discontinuation was finally decided on EU level. Main considerations discussed are displayed in the overview in Table 4.

In order to give a taste of the considerations that were discussed between government and parliament in the making of a discontinuation policy for the Netherlands, we present abstracts of the seven aforementioned considerations $(\mathrm{C} 1-7)$ :

$\mathrm{C} 1$ : In the discussion on the ILB discontinuation, the level of the proposed discontinuation policy is an omnipresent issue. Parliament's focus has always been on supranational regulation.

In a first reaction on the written questions about a possible ban on the ILB, the minister of Economic Affairs and the state secretary of Housing, Spatial Planning and Environment (VROM) at that time explained that the ministry focuses on a European approach ([86], p. 1933). In a subsequent round of written questions from the same member of the Dutch parliament (MP), the same minister and state secretary stated that they cannot initiate any national policy as this issue has already been discussed at supranational level for the creation of an Ecodesign Directive ([87], pp. 2457-8). The newly

\footnotetext{
9 The analysis concentrates on the period between 2007 and 2010. Afterwards, it was only reported that the phase-out takes place as planned and the lamps disappear as intended from the shops (https://zoek.officielebekend makingen.nl/kst-32710-XI-2.html). From 2011, the next target for bans was already the energy-saving lamp accused of increasing the emission of volatile organic compounds. (https://zoek.officielebekendmakingen.nl/ah-tk-20102 011-2603.html, accessed 20 November 2019. Occasionally, right-wing speakers still refer to the custodial act of Brussels, the people of choice to buy bulbs to have taken away (https://zoek.officielebekendmakingen.nl/h-tk-2012201324-21.html, accessed 20 November 2019).
} 
Table 4 Considerations in parliamentary debate

\begin{tabular}{lll}
\hline Policy problems of ILB discontinuation and its trade-offs & C1: Level of policy & National vs. supranational \\
& $\begin{array}{l}\text { C2: Strategy of discontinuation } \\
\text { C3: Pace of regulation }\end{array}$ & $\begin{array}{l}\text { Stimulation vs. ban } \\
\text { regulation in order to foster faster innovation }\end{array}$ \\
$\begin{array}{ll}\text { Policy problems for dealing with consequences of ILB } \\
\text { discontinuation }\end{array}$ & $\begin{array}{l}\text { C4: Replacement costs } \\
\text { C5: Price regulation }\end{array}$ & Intervention high price of bulbs vs. return of investment \\
& C6: Old infrastructure & Price policy vs. regulation by market \\
C7: ILB specificities & Exceptions for (continued) use vs. no exceptions for use \\
\hline
\end{tabular}

appointed VROM Minister also made it clear that she, too, aspires to a European approach ([88], p. 3763-5). In one document, the ministry of VROM acknowledged that the environmental supranational policy is often more efficient and effective compared to national policies. However, due to the specificities of individual countries, they considered it justified to develop a national policy as well ([89], pp. 1-3). Although the supranational orientation in the parliamentary discussion was not very controversial, the minister wanted to emphasise that the Dutch delegation had a great influence on the question and the way in which the ILB was phased out ([90], p. 31).

In general, the ministers and state secretaries responsible-in addition to those of VROM and the Ministry of Economic Affairs and, after 2010, the new Ministry of Infrastructure and Environment-stated that the Dutch government was unable to develop national regulation because of European policy on the same subject. They assured, however, to invest much effort in a supranational policy instead. Although they left space for a specific national policy, the legitimacy of supranational policy did not seem to be a point of discussion.

$\mathrm{C} 2$ : There was no disagreement in the discussion about the discontinuation of the light bulb that energy-efficient lighting should be the norm. However, it has been discussed how this standard needs to be defined.

The VROM minister was clear from the beginning about her goal of banning ILBs. However, several MPs disagreed on a ban and argued in favour of discontinuation by stimulation of the use of energy-efficient lighting ([88], pp. 3763-5). The criticism of a ban was that it would limit consumer choice in favour of the collective interests. Although the ministry acknowledged that a ban is a 'steering measure' ([91], p. 12), the minister believed that there are enough alternatives, so that the choices of consumers are hardly limited ([88], pp. 3765-5).

All the actors wanted to make efforts to make energyefficient lighting the norm. Although the minister decided to ban, some MPs said that this strategy would have too great an impact on consumer choice.

C3: While the phasing out of the ILB took its first step, the discussion about the feasibility of the discontinuation resumed. In particular, the practicability of energy-efficient lighting on the market has been openly challenged by the slow pace of innovation of alternative products.

One MP asked the VROM minister if there was an opportunity to make exceptions to the use of certain ILBs and to slow down the regulation, as energy-efficient lighting is slow to innovate ([92], pp. 8375-8). However, the minister emphasised that the introduction of exceptions to the use of discontinued technology should stimulate innovation. She argued that manufactures need to be innovative, so exceptions are not required and innovation can be expected from them.

While an MP considered the technological development of efficient lighting as a feasibility problem for a complete ban on ILB, the minister wanted to improve the feasibility by adhering to the ban.

C4: The purchase costs were considered by some of the MPs to be a major disadvantage of energy-efficient lighting. The minister of VROM agreed that these high prices could raise a threshold ([92], p. 8356). However, she did not want to make an effort to remove this threshold, because the total return of the investment is far higher than the initial costs, the lamps consume less energy and have a better durability, she argued.

Although it was agreed that the purchase costs could be an economic obstacle, the minister, however, did not want to invest in removing this obstacle as she focused on the profitability of the new light bulbs.

C5: In order to overcome the high purchase costs of energy-efficient lighting, MPs called on the government to take action. A first measure that was discussed was the adjustment of the import duty on energy-efficient lighting ([89], p. 8). The government agreed to this measure and stated that it would try to regulate it at EU level. Another measure demanded of the government was a reduction in VAT on efficient lighting ([92], pp. 8355-6; [93], pp. 361-2). In both documents, MPs asked the minister of VROM whether she wanted to introduce a VAT reduction. The minister replied that the profitability of the investment speaks for itself and that she believes that the growing demand for efficient lighting will allow 
Table 5 The governance dimensions and the trade-offs on the Dutch national level

\begin{tabular}{ll}
\hline Governance dimensions of discontinuation & Trade-offs \\
\hline Policy instruments & Exiting strategy vs. burdens for users \\
Implementation & Burdens of technology replacement vs. burdens for usage \\
Strictness & Forced introduction with no exceptions vs. soft strategy \\
Policy level & Existing supranational policy instead of national policy \\
\hline
\end{tabular}

manufacturers to innovate and automatically lower prices ([93], pp. 361-2; [94], p. 2).

While some of the MPs asked to develop measures to address the economic impact of ILB discontinuation, the minister replied that she believes the market can regulate through innovation.

C6: An important disadvantage of the discontinuation of the IBL discussed is the old lighting infrastructure, which does not match the new light bulbs. This is a consequence of the different shapes of the new bulbs compared to the old bulbs. It is therefore possible that new bulbs do not be compatible with the old fittings of lamps ([88], pp. 376-4; [89], p. 8). The minister of VROM did not believe in an additional transition period for these infrastructural problems and adjustments ([88], pp. 3763-4). She argued that if this becomes a problem manufactures will be forced to solve this.

C7: The ILB has a broad light spectrum and is believed to produce more "natural" light. Energy-efficient lighting is often accused of producing artificial or ugly light. It is argued, as a result, the discontinuation of the ILB can harm light-sensitive people, and one MP asked to leave room for exceptions in the discontinuation policy such as the use of old technology ([92], pp. 8357-8). However, the minister did not want to leave any room for the use of ILBs in particular individual cases. She argued that exceptions are not necessary if manufactures are forced to innovate (ibid.). In addition, the Minister explained that the improved halogen light bulb could serve as a temporal solution for this type of problem ([88], p. 3765).

This brief excursion into the debates and the setting of the agenda shows that, as the heuristic suggest, the choice between ban and positive sanctions is indeed an issue, as well as exceptions for different uses, and the role of regulation as opposed to stimulation could play through incentives (positive sanctions). Both government and MPs not only look at the state side, but also at the market side of phasing out ILBs, and the government assigns an active role to the companies framed by the state actions. It should also be mentioned that part of the discussion took place before and another part even after the introduction of EU legislation. Part of the data covers the continued discussion about the regulation already finalised at EU level-which is interesting because despite or while there was a supranational decision, the MPs still tried to amend the regulation or at least comment through discussions with the minister.

The discontinuation strategy in this area is characterised by a domino effect in which some pioneers made individual attempts that showcased at the Phase-out 2008 conference in Shanghai (such as Cuba and Australia), and later transnational coordinated efforts followed. This case also shows how much a seemingly small technical device such as the light bulb is integrated into a larger sociotechnical regime. The phasing out of the small light bulb has broader implications for infrastructure, the lighting industry consumer goods. In addition, the case is one recent example for termination through redefinition of technical standards.

In summary, we can distinguish four governance dimensions that were at stake in the Dutch parliamentary debate (see Table 5).

The analysis of the debate in parliament resulted in a typology of six governance problems as discussed during the negotiation of a discontinuation policy for the Netherlands (see Table 6). In the following, we show which discontinuation issues know from EU level were also included. Finally, the findings at the national level will be compared with the findings of discontinuation governance at the supranational level in order to provide a more comprehensive and multi-sited picture of the governance targeting ILB discontinuation in the EU.

From the analysis, six different types of governance problems were distinguished. This is a first overview.

The various governance issues reconstructed from the policy documents are explained in the following paragraphs. The governance problems, as discussed by the involved actors, are described in light of the discontinuation issues.

\section{Stimulation vs. ban}

At the national level, there was an on-going discussion about the possibilities of promoting the use of efficient lighting or banning inefficient lighting. From the outset, the minister responsible at VROM was clear about her objective of banning ILBs. However, various MPs disagreed on a ban and argued in favour of discontinuation by stimulating energy-efficient lighting ([88], pp. 
Table 6 Governance problem-related issues on the national level

\begin{tabular}{ll}
\hline Governance problems & Issues \\
\hline Exiting strategy & Stimulation vs. ban \\
Costs of discontinuation & Price policy vs. return of investment for purchase \\
Old infrastructure & Retrofitting vs. need for improvement \\
Innovation policy & Forcing quick vs. facilitating slow innovation \\
Overcoming burdens of technology replacement & Need for exceptions for usage vs. no exceptions \\
Reach of policy & Use of added national vs. existing supranational policy \\
\hline
\end{tabular}

3763-5). The criticism of a ban was the high limitation of consumer choice in favour of common interests. Although the ministry acknowledged that a ban is a 'steering measure' ([91], p. 12), the minister believed that there are enough alternatives, so that there will be a low degree of choice limitation ([88], pp. 3763-5).

At the level of the Dutch parliament, there was no disagreement that energy-efficient lighting should become the norm. However, there was discussion on how this standard should be established. Encouraging the use of the new light sources would involve positive sanctions. The ban on inefficient lighting would include negative sanction. This discussion shows that the choice of an exit strategy involved an important decision on the type of policy instrument to be used for discontinuation. This strategy issue did not occur on the supranational level. Here, the ecodesign framework had already established a ban on the design of particular "inefficient" lighting through standards. At the Dutch level, the minister responsible argued in favour of a ban, although some MPs argued that this strategy would have too great an impact on consumer choice, preventing people from making their own decisions in a free market.

\section{Price policy vs. return of investment for purchase}

At both the national and supranational levels, the costs of eliminating ILBs by replacing them was an issue. At the national level, a possible intervention in the high prices of bulbs was a particular point of discussion. The purchase costs were seen by some MPs as a major burden for users to replace ILBs with the new energy-efficient lighting. In order to overcome the high purchase costs of energy-efficient lighting, MPs called for measures to be taken by the government. A first measure that was discussed was the adjustment of the import duty on energy-efficient lighting ([89], p. 8). The government agreed to this measure and stated that they would try to regulate it at EU level. Another measure demanded from the government is a VAT reduction on efficient lighting ([93], pp. 361-2; 8355-6). The minister of VROM agreed that these high prices could raise a threshold for discontinuation ([92], p. 8356). However, she did not want to bother to remove this threshold, because she argued that the total return on the investment is far higher than the initial costs, the lamps consume less energy and have a better durability.

\section{Retrofitting vs. need for improvement}

At the national level, the old infrastructure for domestic lighting was discussed as issues for discontinuation. An important disadvantage of energy-efficient lighting is that it does not always fit into the old armatures of lamps ([88], pp. 3763-4; [89]: 8). To overcome this burden, an additional transition period was proposed. However, the minister responsible was not in favour of slower implementation ([88], pp. 3763-4), but said that she believed a complete ban would force the manufactures to automatically solve this obstacle.

\section{Forcing quick vs. facilitating slow innovation}

Another discussed burden was the need to stimulate innovation to improve the new technology. While the phasing out of the ILB was made its first step, the discussion about the feasibility of the discontinuation came up again. In particular, the practicability of the energyefficient lighting on the market was openly questioned, due to the slow pace of innovation and the possibility of exceptions raised. The minister argued that manufactures must always be innovative anyway, so exceptions would not be necessary, and innovation will be imposed on them. The pace of the implementation of discontinuation was thus used to drive innovation.

\section{Need for exceptions for usage vs. no exceptions}

As a reaction on the performance issues raised and the need for improvement of efficient lighting, the strictness of discontinuation became a topic of discussion in the Dutch parliament. Light-sensitive people could be disadvantaged by an ILB ban, it was said. Asked to leave room for exceptions ([92], pp. 8357-8), the minister refused. She argued that pressure to innovate would make exceptions unnecessary ([92], pp. 8357-8), and that improved halogen light bulb could serve as a temporal solution ([88], p. 3765). Thus, the strictness of governance was discussed as a means to overcome the burdens of the 
Table 7 The governance dimensions and the related problems on national level

\begin{tabular}{lll}
\hline Governance dimensions & Problem-types & Discontinuation issues \\
\hline Policy instruments & Exiting strategy & Positive vs. negative sanctions \\
& Burdens of/for users & Costs of discontinuation \\
Implementation & Burden replacing technology & Need for improvement \\
Strictness & Burdens of infrastructure & Retrofitting \\
& Burden replacing technology & Performance issues \\
Policy level & & Need for improvement \\
\hline
\end{tabular}

replacing technology. The minister felt that strict regulation to overcome these burdens would be most effective.

\section{Use of added national vs. existing supranational policy}

Although the supranational focus was not very controversial in the Dutch parliamentary discussion, the minister wanted to emphasise that the Dutch delegation had a lot of influence on the subject and the phasing out policies at EU level ([89], p. 31), while the Dutch government could not develop a national regulation due to the existing European policy on this subject. They assured, however, that instead they would put a lot of effort in a supranational policy. The legitimacy of supranational policy did not seem to be a point of discussion.

\section{Second intermediate conclusion}

Although the Dutch government did not have or claim the authority to establish a national policy on discontinuation independent of the EU, several governance dimensions were taken into account in the parliamentary debate. All in all, firstly, it is interesting that-according to the audible voices in parliament-it should be left to the forces of the free market which lamps survive, although this option has long since been abandoned by the strategy of the lighting industry to change the market through state intervention, because experience has shown that the market would not be able to do it on its own so far. The emphasis on the free market, if it was not ignorance of the reality of the industry's strategy, can be understood as a conflict between the interests of the lighting industry and those of consumers who actually had to say goodbye to a socio-technical device, the light bulb, which most consumers did not really want to get rid of.

Secondly, while the industry wanted a change, but at a slower pace until the replacement products were mature enough, the Dutch government and the European Commission took the initiative and pushed the industry to speed up efforts to bring the replacement products to market maturity. This is another tension that has challenged industry by calling for state intervention. Other analyses we have carried out at EU level have shown that the Commission and the Member States have often indeed taken a middle position, compared with an even faster ban on inefficient light bulbs, which the environmental NGOs wanted, and the slower pace which industry would have preferred ([95]; publication in preparation). Thirdly, the case shows that it was clear to everyone that issues such as the quality of energy-saving light bulbs and retrofitting would be partly postponed to achieve a goal now, with confidence in the flow of innovation into which the world of lighting products had entered, confidence that there would soon be the right solutions, even if they are not yet directly available.

Table 7 presents a structured overview of the discontinuation issues that were identified by the actors in the previous section and of how the related discontinuation issues substantiate the governance problems. Here, we integrate the national discontinuation issues with those on EU level in order to establish comparability.

In the remaining part of Sect. 5, we will elaborate briefly on the abstracted discontinuation issues that we were able to identify regarding the described governance problems. In addition to these issues, also the governance dimensions that the Dutch parliamentary discourse considered are mentioned.

\section{Discussion \\ Overview and comparison of issues and governance dimensions}

Finally, the discussed governance dimensions and discontinuation issues on EU (Table 3) and national level (Table 7) will be compared and discussed.

A first look at both tables shows that many of the governance dimensions we distinguished have been discussed on both levels. From five dimensions on the supranational level, four dimensions were present on the national level. Only the governance dimension of monitoring did not occur explicitly in the Dutch debate. How so? The supranational approach for the final regulation on the ILB discontinuation was framed within the EU 
Table 8 An integration of the issues on both levels

\begin{tabular}{|c|c|c|}
\hline Governance dimensions & Problem-types & Discontinuation issues \\
\hline \multirow[t]{12}{*}{$\underline{\text { Policy instruments }}$} & Burdens of replacing technology & Performance issues \\
\hline & & Impact of production and use of resources \\
\hline & & Recycling \\
\hline & & Health issues \\
\hline & Burdens of/for users & Awareness raising for need of discontinuation \\
\hline & & Need of knowledge for replacement \\
\hline & & Comparison of light output of new lamps \\
\hline & & Image-issues \\
\hline & & Stockpiling of ILBs \\
\hline & & Costs of discontinuation \\
\hline & Burdens of infrastructure & Need for new eco-labelling \\
\hline & Exiting strategy & Positive vs. Negative sanctions \\
\hline \multirow[t]{4}{*}{ Implementation } & Challenges for industry & Capacity for new production \\
\hline & & Production loss due to discontinuation \\
\hline & Burdens of replacing technology & Need for improvement \\
\hline & Burdens of infrastructure & Retrofitting \\
\hline \multirow[t]{4}{*}{$\underline{\text { Strictness }}$} & Burdens of replacing technology & $\underline{\text { Performance issues }}$ \\
\hline & & Need for improvement \\
\hline & Burdens of infrastructure & Retrofitting \\
\hline & & Dim-installation \\
\hline \multirow[t]{4}{*}{ Monitoring } & Burdens of replacing technology & Recycling \\
\hline & & Health issues \\
\hline & Burdens of/for users & Image-issues \\
\hline & Challenges for industry & Circumvention of industry \\
\hline \multirow[t]{3}{*}{ Policy level } & Existing regulations & National level \\
\hline & & Supranational level \\
\hline & & International level \\
\hline
\end{tabular}

governance framework, which automatically made the monitoring an issue of supranational market surveillance. Furthermore, as long as the ILB is not yet completely phased out, monitoring could still have become an issue on the national level. It has not, as we know today.

Secondly, the table of the supranational level contains many more discontinuation issues than the national level. This shows that the discontinuation governance at the supranational level included a wider range of discontinuation issues that were more extensively identified by the actors involved. This could be the result of the multiactor constellation in the EU policymaking trajectory. At the supranational level, there was also much more indepth discussion on the establishment of a final discontinuation regime. This could also indicate that the ILB ban is mainly a governance issue at EU level that has not

\footnotetext{
10 The single underlined issues correspond on both levels and the issues in italics were not present at the supranational level.
}

completely been challenged at Dutch national level and fought at every turn.

The integration of both tables in Table 8 shows the overlap of both discontinuation situations. ${ }^{10}$

Table 8 suggests that the national level complemented the table of the supranational level of many parts. First of all, the analysis of the national introduced an additional problem-type, namely the exiting strategy of a discontinuation policy. In the Dutch parliament this problem-type was a highly debated point of interest, although this issue was not mentioned on the supranational level. The exit strategy appeared to be important before any policy was defined. However, when the supranational policymaking started, the discontinuation was already positioned within the ecodesign framework. As a result, this framework pre-structured the regulation by setting ecodesign requirements, which involved negative sanctioning from the start. Secondly, in addition to exiting strategy, the table shows that unlike the supranational level, the national level considered the implementation of a discontinuation policy an important governance dimension: as 
a way to overcome issues with retrofitting and the need for improvement of efficient lighting by a gradual implementation of a regulation.

This excursion into debates and agenda setting indicates that, as the heuristic suggests, in fact the choice between ban and positive sanctions is an issue, as well as exceptions for different usages, and the question which role regulation could play as opposed to stimulation by incentives (positive sanctions). Both the government and members of parliaments consider not only the state side, but also the market side of phasing out ILBs, and the government assigns an active role to the companies derived and framed through the way the state acts.

For the discontinuation of the ILB, it was apparent how important the political strategy was for the actual phaseout. Although the industry and market were adjusting, the government did not seem to believe that the transition was good and fast enough, and wanted to encourage this with negative sanctions and set new standards that would impact industry, sellers, and users. The discontinuation strategy in this field is characterised by a domino effect, in which some pioneers made solo attempts, and later followed transnational coordinated efforts. This case also shows how much a seemingly small technical device such as the light bulb is bound into a larger sociotechnical regime. The phase-out of the small light bulb has far-reaching effects on the infrastructure, on lighting industries and on consumer products. In addition, the case is one recent example for termination by redefining technical standards.

In further publications on the subject, we will also analyse the importance of industry, what it did for the exit and where it came to the limits of its influence. For this article, we also did not consider the negotiation of the exit itself as a process, but only the framing, with the help of which the phase-out from the ILBs was accomplished. Since the material at hand is already very extensive, we would like to forego further branches and layers of the analysis and refer to further, supplementary publications.

\section{Conclusions}

\section{Discontinuation governance patterns}

The analysis has shown that at the level of discursive negotiation and the aspects explicitly dealt with there, particular effort was made to pay attention to the further design of policy instruments, implementation, factual and regulatory strictness and monitoring. Discontinuation governance first had to create the instruments and practise their use. This is not a daily routine-generally not, and at that time also not for the as yet untested procedure for dealing with ecodesign and energy-using products. In order to give the implementation a chance, an attempt was made to include the expertise of the stakeholders and to negotiate a reasonably acceptable compromise for everyone. Nobody was completely satisfied, nobody was completely disappointed, so it was doable. Strictness indicates that one wanted to be both strict and precise: technical conditions and necessities, industrial and environmental policy measures were included. At the same time, rather strict criteria were formulated for the exclusion of the old and the approval of the new technology. Bridge technologies, such as the by no means perfect energy-saving and halogen lamps, should also be made possible without stipulating their limited justifiability in the long term. In order for these rules to be taken seriously, they had to be monitored and enforced. The necessary mechanisms were created in such a way that they had an effect of scale, but would not necessarily completely criminalise small violations, for example in trade (e.g., occasional stockpiling of and grey internet market for ILBs). This adds an important aspect to the literature on 'policy termination': the reference to the fact that we are not only dealing with the termination of policy, but also with the creation of instruments and policies to get the discontinuation done. Below we interpret this conceptually as 'governance of discontinuation'.

As far as the policy level is concerned, we have already mentioned the tensions over legitimacy and responsibility, some of which are to be understood as placeholders for defensive battles against an unpopular change in the choice of light source. It needs to be added that, at the core of our case's negotiations, many agreed that one would like to shape the phase-out at EU level, because this is the only way to position the entire economic area reasonably coherently towards China and the USA, for example. Once again, however, it has also been shown that member states could certainly have their own accents and speeds in order to get a workable overall concept. This shows, in an example rather unusual for the debate about EU multi-level governance [96, 97], how interrelated, complex, and ultimately dependent the levels in the EU policy process are. What we have to add, of course, is the emphasis that the negotiating structure also includes forms and NGOs, media and lobby groups. The levels are by no means only related to the state, but-as the term governance indicates as the description of the delimitation of government action-applies to all actors.

The present study reaches its limits when it comes to the interaction between different $\mathrm{EU}$ member states and the struggle within the commission about the lightbulb ban. We have only shown by way of example how political and technical (including design and standardisation-related) aspects are shaped by governance in order to enable discontinuation. Of course, more research is needed to better understand exit governance. We notice that further projects are being carried out on this topic 
as well as on destabilisation [98] and decline or decay $[24,99,100]$, which complement each other well with the focus on actively governed discontinuation.

\section{Discontinuation governance as strategic challenge}

The presented research approach towards the governance of the discontinuation of socio-technical regimes shows, firstly, that the latter takes place in a highly complex context-technically as well as socially-and, secondly, in most cases discontinuation has to cope with some resistance to dedicated, forced change. Not surprisingly, despite a potentially strong political will, institutional inertia and vested interests may prevail (cf. [101]). Discontinuation governance has to manage the unbundling of forces, the dismantling of existing structures in order to overcome inertia of current systems and networks. At the same time, as in our case, it has the task of politicising technology and of technologically influencing policy and governance, for instance by setting the regulatory and public investment framework for revolutionary lighting technology (e.g., LED and semiconductors). Technical and environmental standards (here, e.g., in terms of ecodesign and energy-efficiency) may lead to the prohibition of old and the triumph of new products and sociotechnical regimes configurations.

Thirdly, the above-mentioned heuristic (Table 1) so far only implicitly addresses aspects like practice and culture (e.g., as knowing what, when and how to discontinue and to build the necessary agendas and networks) or power (enforcing something in coalitions). Adding these aspects in further research may help to draw the fuller picture. As regards the retrofitting of light bulbs, some cultural aspects have already been addressed, since this is not only a technical problem, but also relates to the habits of using light in built environments, of having special, long-established designs and lighting methods, lamp sockets, which refers also to use, habituation, and aesthetic aspects. Fourthly, a close look at the (types of) actors and interaction involved in the dedicated governance of discontinuing technologies and regimes is also required, if the concept of discontinuation governance shall encompass the full complexity of the interconnectedness of structure, process and action. Some results require more attention, such as the silence and absence of employee representatives from the ILB discontinuation negotiations. Another finding, related to 'strictness', is, for instance, that rather a new coalition advocating a specific direction of change emerged (cf. $[102,103])$ : partial collaboration and agreements for more energy-efficient lighting between industry and environmental NGOs, while free market liberalists representing consumer interests would rather be at odds with the industry. Change seems to swirl the usual order structure. Change, especially those radical ones, as in relation to discontinuation, also seem to cause conflicts about who bears which 'burden'. Fifthly, more comparative research on various kinds of cases should allow for developing a typology of pathways or generalised 'discontinuation journeys' (cf. $[104,105])$.

In the methodology section, we already indicated the technoscientific and political details as well as their combinations, which the governance practitioners must address. Governing the phase-out of a technical device, a production infrastructure, and industry support policy once supposed to support the EU and Dutch ILB industry was a major techno-political challenge, where policymakers needed to grasp key technical and technological problems. These were related to ILBs as objects, to subjects such as engineers and scientists, lobbyists and disinterested experts, to civil society organisations and mass media, along with all sorts of political and administrative issues and discourses. The challenges are threefold: first, translating for each other what cannot be known from one's own background, second, shutting down governance which so far fostered lighting industry and, third, helping to change parts of this industry from an old, incumbent one to a new, emerging socio-technical regime with a regime providing a political and regulatory framework for it.

Overall, the present technical policy review shows us, from a historical perspective, that the subsequent developments-such as the phase-out of halogen lamps and energy-saving lamps containing mercury-should also be examined. What began with the ILBs has continued. Have new routines really developed here on how to get rid of technology politically? Is the ability of governance makers to organise the exit from existing technologies and socio-technical regimes more and more important? These questions are still unanswered empirically.

\begin{abstract}
Acknowledgements
We thank the reviewers and Carina C. Liersch for their valuable critical and thorough feedback on earlier versions of this article. We also thank the participants of the 2012 Jean Monnet Conference 'The Governance of Innovation and Socio-Technical Systems in Europe: New Trends, New Challenges', an international workshop at Copenhagen Business School, Denmark, and at 2012 4S/EASST Conference, Panel on 'The governance of innovation and socio-technical systems: design and displacements—l'at Copenhagen Business School, Denmark, for their comments on the very first presentations and versions of this text.
\end{abstract}

\section{Authors' contributions}

VRV and PS were responsible for the conceptualisation and design of the study. VRV carried out the main data collection and analysis, supervised by PS. SK complemented the theoretical part and fed in feedback from both 2012 conferences and later presentations. PS authored the current version of the paper, and both VRV and SK provided relevant feedback for the improvement of the article's clarity. All authors read and approved the final manuscript.

\section{Funding}

The article presents research undertaken in the context of a project by a consortium of researchers from the Netherlands (Peter Stegmaier, Stefan 
Kuhlmann), United Kingdom (Andrew Stirling, Philip Johnston, Frank Geels), France (Pierre-Benoit Joly, Alix Levain, Fanny Pellisier, Marc Barbier, Frank Dedieu), and Germany (Johannes Weyer, Marc Mölders, Jessica Longen, Sebastian Hofmann). The research for this paper has been enabled through the Open Research Area Scheme (ORA) Grant no. 464-11-057 from NWO, DFG, ANR and ESRC within the project called 'Governance of the discontinuation of socio-technical systems' (DiscGo). The article also profits from the pilot study undertaken by Vincent Ruben Visser for his master thesis.

\section{Availability of data and materials}

The datasets generated and analysed during the current study are not publicly available due to confidentiality reasons. However, the transcripts of the anonymous interviews are available on reasonable request.

\section{Declarations}

\section{Ethics approval and consent to participate}

Not applicable.

\section{Consent for publication}

All participants consented the confidential publication of their contributions in this study.

\section{Competing interests}

The authors declare that they have no competing interests.

\section{Author details}

'Department of Technology, Policy \& Society (TPS), Science, Technology and Policy Studies (STePS) Section, University of Twente, Postbus 217, 7500 AE Enschede, Netherlands. ${ }^{2}$ Esplanade de Meer 7, 1098WH Amsterdam, Netherlands.

Received: 9 December 2019 Accepted: 12 April 2021

Published online: 29 April 2021

\section{References}

1. Kemp R (1994) Technology and the transition to environmental sustainability - the problem of technological regime shifts. Futures 26:1023-1046

2. Helmstädter E, Perlman M (1996) Behavioral norms, technological progress, and economic dynamics. University of Michigan Press, Ann Arbor

3. Hekkert MP, Suurs RAA, Negro SO, Kuhlmann S (2007) Functions of innovation systems: a new approach for analyzing technological change. Technol Forecast Soc Chang 74:413-432

4. IEA (2018) In this report. World Energy Outlook 2018. www.iea.org/ reports/world-energy-outlook-2018. Accessed 9 Dec 2019.

5. IEA (2017) About this report. Energy technology perspectives 2017. www.iea.org/reports/energy-technology-perspectives-2017. Accessed 9 Dec 2019

6. Schot J, Steinmueller WE (2018) Three frames for innovation policy: $R \& D$, systems of innovation and transformative change. Res Policy 47:1554-1567

7. Geels FW, Schot J (2007) Typology of sociotechnical transition pathways. Res Policy 36:399-417

8. Bergman $L$ (1980) The economic impact of nuclear power discontinuation in Sweden. WP-80-97. International Institute for Applied Systems Analysis, Laxenburg

9. Schumpeter J (1942) Capitalism, socialism and democracy. Harper \& Brothers, New York

10. Mayntz R, Hughes TP (eds) (1988) The development of large technical systems. Campus, Frankfurt/M

11. Coutard O (2002) The governance of large technical systems. Routledge, London

12. Schneider V, Bauer JM (2009) Von der Governance zur Komplexitätstheorie. Entwicklungen der Theorie gesellschaftlicher Ordnung. In: Weyer J, Schulze-Schaeffer I (eds) Management komplexer Systeme. Konzepte für die Bewältigung von Intransparenz, Unsicherheit und Chaos. Oldenbourg, München
13. Garud R, Karnøe P (2001) Path creation as process of mindful deviation. In: Garud R, Karnøe P (eds) Path dependence and creation. Erlbaum, Mahwah

14. Meyer U, Schubert C (2007) Integrating path dependency and path creation in a general understanding of path constitution. The role of agency and institutions in the stabilisation of technological innovations. Sci Technol Innov Stud 3:23-44

15. Geels FW (2007) Transformations of large technical systems: a multilevel analysis of the dutch highway system (1950-2000). Sci Technol Hum Values 32:123-149

16. Markard J, Truffer B (2006) Innovation processes in large technical systems: market liberalization as a driver for radical change. Res Policy 35:609-625

17. Konrad K, Markard J, Ruef A, Truffer B (2012) Strategic responses to fuel cell hype and disappointment. Technol Forecast Soc Chang 79:1084-1098

18. Latour B (1992) Aramis, ou l'amour des techniques. Le Découverte, Paris

19. Latour B (2002) Aramis, or the love of technology. Harvard UP, Cambridge

20. Hoffmann S, Weyer J, Longen J (2017) Discontinuation of the automobility regime. An integrated approach to multi-level governance. Transp Res Part A 103:391-408

21. Mujkic E, Klingner D (2018) Dieselgate: how hubris and bad leadership caused the biggest scandal in automotive history. Public Integr 21:365-377

22. Di Rattalma MF (ed) (2017) The dieselgate. A legal perspective. Springer, Cham

23. Andersen O, Upham P, Aali C (2018) Technological response options after the $\mathrm{VW}$ diesel scandal: implications for engine $\mathrm{CO} 2$ emissions. Sustainability 10:2313

24. Isoaho K, Markard J (2020) The politics of technology decline: discursive struggles over coal phase-out in the UK. Rev Policy Res 37:342-368. https://doi.org/10.1111/ropr.12370

25. Johnstone P, Stirling A (2020) Comparing nuclear trajectories in Germany and the United Kingdom: from regimes to democracies in sociotechnical transitions and discontinuities. Energy Res Soc Sci 59:101245. https://doi.org/10.1016/j.erss.2019.101245

26. Cox E, Johnstone P, Stirling A (2016) Understanding the intensity of UK policy commitments to nuclear power. SPRU working paper series SWPS 2016-16.

27. Verbong G, Geels FW (2010) Exploring sustainability transitions in the electricity sector with socio-technical pathways. Technol Forecast Soc Change 77:1214-1221

28. Wilson C, Grubler A, Gallagher KS, Nemet GF (2012) Marginalization of end-use technologies in energy innovation for climate protection. Nat Clim Change 2:780-788

29. Turnheim B, Sovacool BK (2020) Exploring the role of failure in sociotechnical transitions research. Environ Innov Soc Trans 37:267-289. https://doi.org/10.1016/j.eist.2020.09.005

30. Olleros FJ (1986) Emerging industries and the burnout of pioneers. J Prod Innov Manag 1:5-18

31. Weber M, Rohracher H (2012) Legitimizing research, technology and innovation policies for transformative change. Combining insights from innovation systems and multi-level perspective in a comprehensive 'failures' framework. Res Policy 41:1037-1047

32. Feola G, Nunes R (2014) Success and failure of grassroots innovations for addressing climate change: the case of the transition movement. Glob Environ Change 24:232-250

33. Geels FW (2002) Technological transitions as evolutionary reconfiguration processes: a multi-level perspective and a case-study. Res Policy 31:1257-1274

34. Nelson RR, Winter SG (1982) An evolutionary theory of economic change. Belknap, Cambridge

35. Konrad K, Markard J, Truffer B (2006) Analysing the interaction of an innovation field and its context for exploring different innovation pathways: the case of Smart Building. Paper presented at the SPRU 40th Anniversary Conference: The Future of Science, Technology \& Innovation Policy: Linking Research and Practice, September 11-13, 2006.

36. Smith A, Stirling A, Berkhout F (2005) The governance of sustainable socio-technical transitions. Res Policy 34:1491-1510 
37. Geels FW (2011) The multi-level perspective on sustainability transitions: responses to seven criticisms. Environ Innov Soc Trans 1:24-40

38. McKinsey \& Company (2012) Lighting the way: perspectives on the global lighting market, 2nd edn. August 2012

39. IEA (2006) Light's labour's lost. Policies for energy-efficient lighting. In support of the G8 plan of action. Energy efficiency policy profiles. OECD/IEA, Paris

40. Elzen B, Geels FW, Green K (2004) System innovation and the transition to sustainability: theory, evidence and policy. Elgar, Cheltenham

41. Markard J, Raven R, Truffer B (2012) Sustainability transitions: an emerging field of research and its prospects. Res Policy 41:955-967

42. Turnheim B, Geels FW (2012) Regime destabilisation as the flipside of energy transitions: lessons from the history of the British Coal Industry (1913-1997). Energy Policy 50:35-49

43. Utterback J (2003) The dynamics of innovation, in the internet and the university, Aspen Institute Forum 2002, Educause, 81-103. https://er. educause.edu/articles/2004/1/the-dynamics-of-innovation. Accessed 21 Aug 2020

44. Hoppe R (2010) The governance of problems. Puzzling, powering and participation. Policy Press, Bristol

45. Rogge KS, Johnstone P (2017) Exploring the role of phase-out policies for low-carbon energy transitions: the case of the German Energiewende. Energy Res Soc Sci 33:128-137

46. Betsill MM (2017) Trump's Paris withdrawal and the reconfiguration of global climate change governance. Chin J Popul Resour Environ 15:189-191

47. Stegmaier P, Kuhlmann S, Visser VR (2014) The discontinuation of sociotechnical systems as governance problem. In: Borrás S, Edler J (eds) Governance of systems change. Edward Elgar, Cheltenham

48. Bauer MW (2009) The policy termination approach: critique and conceptual perspectives. www.sowi.hu-berlin.de/de/lehrbereiche/ ehemalige-lehrbereiche/politikundverwaltung/wps/working-paper-1. Accessed 16 June 2020

49. Bardach E (1976) Policy termination as a political process. Policy Sci 7:123-131

50. Bauer MW, Jordan A, Green-Pedersen C, Héritier A (eds) (2012) Dismantling public policy. Preferences, strategies, and effects. Oxford UP, Oxford

51. Behn RD (1978) How to terminate a public policy: a dozen hints for the would-be policy terminator. Policy Anal 4:393-414

52. Brewer GD (1978) Termination: hard choices, harder questions. Public Adm Rev 38(4):338-344

53. De Leon $P$ (1978) A theory of policy termination. In: May JV, Wildavsky AB (eds) The policy cycle. Sage, Beverly Hills

54. Van de Graaf H, Hoppe R (1996) Beleid en politiek. Een inleiding tot de beleidswetenschap en de beleidskunde. Coutinho, Bussum

55. Hogwood BW, Gunn LA (1984) Policy analysis for the real world. Oxford UP, Oxford

56. Hall P (1986) Governing the economy: the politics of state intervention in Britain and France. Oxford UP, New York

57. Strauss A (1993) Continual permutations of action. Aldine de Gruyter, New York

58. Kuhlmann S (2007) Governance of research-nine comments on Arthur Benz. In: Jansen D (ed) New forms of governance in research organizations. From disciplinary theories towards interfaces and integration. Springer, Heidelberg

59. Stegmaier P, Visser VR, Kuhlmann S (2012a) Governance of the discontinuation of socio-technical systems - an exploratory study of the incandescent light bulb phase-out. In: Paper presented at the 4S/EASST conference, panel on The governance of innovation and sociotechnical systems: design and displacements—I, Copenhagen Business School, Denmark

60. Stegmaier P, Kuhlmann S, Visser VR (2012b) Governance of the discontinuation of socio-technical systems. In: Paper presented at the Jean Monnet conference: the governance of innovation and socio-technical systems in Europe: new trends, new challenges, international workshop, Copenhagen Business School, Denmark

61. Johnstone P, Stirling A (2016) Understanding the intensity of UK policy commitments to nuclear power. SPRU working paper series SWPS 2016-16.
62. Gabel HL (1995) Environmental management as a competitive strategy. In: Folmer H, Gabel HL, Opschoor H (eds) Principles of environmental and resource economics. Elgar, Cheltenham

63. Turnbull N (2018) Policy as (Mere) problem-solving. In: Colebatch $\mathrm{H}_{\text {, }}$ Hoppe R (eds) Handbook on policy, process and governing. Elgar, Cheltenham

64. European Union (2005) Directive 2005/32/EC for establishing a framework for the setting of ecodesign requirements for energy-using products. https://eur-lex.europa.eu/legal-content/EN/TXT/PDF/?uri= CELEX:32005L0032\&qid=1597839053216\&from=EN. Accessed 19 Aug 2020

65. European Commission (2005) Methodology study eco-design of energy-using products. Final report. MEEUP methodology report. DG ENTR, Unit ENTR/G/3, Brussels

66. Rein M, Schön DA (1993) Reframing policy discourse. In: Fischer F, Forrester $F$ (eds) The argumentative turn in policy analysis and planning. Duke UP, Durham

67. Strauss A, Corbin J (2008) Basics of qualitative research. Techniques and procedures for developing grounded theory. Sage, Newbury Park

68. Edge J, McKeen-Edwards H (2008) Light bulbs and bright ideas? The global diffusion of a ban on incandescent light bulbs. In: 80th annual conference of the Canadian political science association. University of British Colombia

69. European Commission (2009c) SEC(2009)328: full impact assessment

70. ELC (2007) The ELCs proposal for domestic lighting. ELC background document domestic lighting, 5th June 2007. Brussels

71. European Parliament (2007a) DCL(2007)0029: on introducing a prohibition on the sale of incandescent light bulbs in the European Union. www.europarl.europa.eu/sides/getDoc.do?pubRef=-//EP//NONSG $\mathrm{ML}+\mathrm{WDECL}+\mathrm{P6}-\mathrm{DCL}-2007-0029+0+\mathrm{DOC}+\mathrm{PDF}+\mathrm{V0} / / \mathrm{EN} \&$ language $=$ EN. Accessed 30 Aug 2019

72. European Union (2009) Directive 2009/125/EC for establishing a framework for the setting of ecodesign requirements for energy-related products (recast). http://eur-lex.europa.eu/LexUriServ/LexUriServ.do? uri=OJ:L:2009:285:0010:0035:en:PDF. Accessed 30 Aug 2019

73. Vito (2009a) Preparatory studies for eco-design requirements of Eups: final report lot 19: domestic lighting

74. European Commission (2008) H-0508/08: Question no 94 by Ivo Belet. www.europarl.europa.eu/sides/getDoc.do?type $=$ CRE\&reference $=$ 20080710\&secondRef $=$ ANN-01\&language $=E N \&$ detail $=\mathrm{H}-2008-0508 \&$ query=QUESTION. Accessed 30 Aug 2019

75. European Commission (2009a) Regulation 244/2009: Implementing Directive 2005/32/EC of the European Parliament and of the Council with regard to ecodesign requirements for non-directional household lamps. http://eur-lex.europa.eu/LexUriServ/LexUriServ.do?uri=OJ:L: 2009:285:0010:0035:en:PDF. Accessed 30 Aug 2019

76. European Commission (2009d) SEC(2009)327 Accompanying document to the Commission Regulation implementing Directive 2005/32/ EC of the European Parliament and of the Council with regard to ecodesign requirements for nondirectional household lamps. FULL IMPACT ASSESSMENT

77. Consultation Forum (2008a) Working document on possible ecodesign requirements for general lighting equipment. ("Domestic lighting part 1, including incandescent bulbs"). Annex 2. http://www.eup-netwo rk.de/fileadmin/user_upload/Produktgruppen/Lots/Working_Docum ents/Lot_19_WD_on_general_lighting_part_1.pdf. Accessed 21 Aug 2020

78. CELMA (2008) CELMA comments on the Commission's documents on possible ecodesign requirements for general lighting equipment. For discussion at the EuP Consultation Forum meeting on 28th of March 2008. Final version 20/03/2008

79. Vito (2009b) Preparatory studies for eco-design requirements of Eups: project report lot 19: domestic lighting

80. ELC (2008) The European lamp industry's strategy for domestic lighting: frequently asked questions \& answers on energy efficient lamps

81. European Commission (2009b) MEMO/09/368 FAQ: Phasing out conventional incandescent bulbs. https://ec.europa.eu/commission/press corner/detail/en/MEMO_09_368. Accessed 21 Aug 2020

82. ELC (2005) Comments on the Council common position on the framework directive on energy using products. February 2005 
83. Consultation Forum (2008b) Minutes of the meeting of the eco-design consultation forum held on 28 March 2008

84. European Parliament (2007a) Written declaration on introducing a prohibition on the sale of incandescent light bulbs in the European Union 0029/2007

85. European Parliament (2009b) Debates: 18. One-minute speeches on matters of political importance. www.europarl.europa.eu/sides/getDoc do?pubRef=-\%2ff2fEP\%2f\%2fTEXT\%2bCRE\%2b20091007\%2b/TEM018\%2bDOC\%2bXML\%2bVO\%2f\%2fEN\&language=EN. Accessed 24 Sept 2020

86. Tweede Kamer (2007a) Aanhangsel van Handelingen 903: 1933. https:// zoek.officielebekendmakingen.nl/ah-tk-20062007-903.html. Accessed 24 Sept 2020

87. Tweede Kamer (2007b) Aanhangsel van de handelingen 1158. https:// zoek.officielebekendmakingen.nl/ah-tk-20062007-1158.html. Accessed 24 Sept 2020

88. Tweede Kamer (2007c) Vragenuur 70: 3764. https://zoek.officieleb ekendmakingen.nl/h-tk-20062007-3763-3765.html. Accessed 24 Sept 2020

89. Tweede Kamer (2008a) 31700 XI, nr 5, Vaststelling begroting Ministerie van Volkshuisvesting, Ruimtelijke Ordening en Milieubeheer (XI) en Waddenfonds 2009. https://zoek.officielebekendmakingen.nl/kst31700-Xl-5.html. Accessed 24 Sept 2020

90. Tweede Kamer (2008b) 31 209, nr 62, Schoon en zuinig: verslag van een notaoverleg. https://zoek.officielebekendmakingen.nl/kst-31209-62. html. Accessed 24 Sept 2020

91. VROM (2010) Energiegedrag in de woning: Aanknopingspunten voor de vermindering van het energieverbruik in de woningvoorraad. http:// ikregeer.nl/documenten/blg-55502. Accessed 19 Feb 2012

92. Tweede Kamer (2009a) Vragenuur 104:8355-8358. https://zoek.offic ielebekendmakingen.nl/h-30397.html. Accessed 24 Sept 2020

93. Tweede Kamer (2009b) Aanhangsel van de handelingen, 170. https:// zoek.officielebekendmakingen.nl/ah-tk-20092010-170.html. Accessed 24 Sept 2020

94. Tweede Kamer (2010) Aanhangsel van de handelingen, 1626. https:// zoek.officielebekendmakingen.nl/ah-tk-20092010-1626.html. Accessed 24 Sept 2020

95. Stegmaier, $\mathrm{P}$ (2017) The reflexive creation of exiting: the governance of discontinuation. In: Paper presented at the summer school'perspectives on innovation society', Berlin, 17 June 2017
96. Hooghe L, Marks G (2003) Multi-level governance and European integration. Rowman \& Littlefield, Lanham

97. Piattoni S (2010) The theory of multi-level governance: conceptual, empirical and normative challenges. Oxford UP, Oxford

98. Köhler J, Geels FW, Kern F, Markard J, Onsongo E, Wieczorek A et a (2019) An agenda for sustainability transitions research: state of the art and future directions. Environ Innov Soc Trans 31:1-32

99. Markard J (2018) The next phase of the energy transition and its implications for research and policy. Nat Energy 3:628-633. https://doi.org/ 10.1038/s41560-018-0171-7

100. Fesenfeld LP (2020) Glimpses of hope: a global green new deal is feasible. SSRN. https://doi.org/10.2139/ssrn.3709074

101. Geels FW (2014) Regime resistance against low-carbon transitions: introducing politics and power into the multi-level perspective. Theory Cult Soc 31:21-40

102. Markard J, Suter M, Ingold K (2016) Socio-technical transitions and policy change: advocacy coalitions in Swiss energy policy. Environ Innov Soc Trans 18:215-237

103. Sabatier PA (1988) An advocacy coalition framework of policy change and the role of policy-oriented learning therein. Policy Sci 21:129-168

104. Van de Ven AH, Polley D, Garud R, Venkataraman S (1999) The innovation journey. Oxford UP, New York

105. Stegmaier P (2019) Killing the Coal. On governing the discontinuation of coal energy production. In: Paper presented at the Nordic STS conference; Session: how do technologies die?, 14 June 2019, Tampere

106. European Parliament (2010) E-1482/10EN answer given by Mr Oettinger on behalf of the Commission (3.5.2010). www.europarl.europa. eu/sides/getAllAnswers.do? reference $=\mathrm{E}-2010-1482 \&$ language $=E N$. Accessed 24 Sept 2020

107. European Parliament (2009a) P-0146/09EN Answer given by Mr Piebalgs on behalf of the Commission (11.2.2009)

\section{Publisher's Note}

Springer Nature remains neutral with regard to jurisdictional claims in published maps and institutional affiliations.
Ready to submit your research? Choose BMC and benefit from:

- fast, convenient online submission

- thorough peer review by experienced researchers in your field

- rapid publication on acceptance

- support for research data, including large and complex data types

- gold Open Access which fosters wider collaboration and increased citations

- maximum visibility for your research: over $100 \mathrm{M}$ website views per year

At $\mathrm{BMC}$, research is always in progress.

Learn more biomedcentral.com/submissions 